\title{
Type I Adenylyl Cyclase Mutant Mice Have Impaired Mossy Fiber Long-Term Potentiation
}

\author{
Enrique C. Villacres, Scott T. Wong, Charles Chavkin, and Daniel R. Storm \\ Department of Pharmacology, University of Washington, Seattle, Washington 98195
}

Long-term potentiation (LTP) at the mossy fiber $\rightarrow$ CA3 pyramidal cell synapse in the hippocampus is an NMDA-independent form of LTP that requires cAMP-dependent protein kinase (PKA) activity and can be induced by forskolin, a general activator of adenylyl cyclases. Presynaptic $\mathrm{Ca}^{2+}$ influx and elevated CAMP may be obligatory for mossy fiber LTP. Because the $\mathrm{Ca}^{2+}$-stimulated type 1 adenylyl cyclase (AC1) is expressed in the dentate gyrus and CA3 pyramidal cells, it is hypothesized that AC1 may be critical for mossy fiber LTP. To test this hypothesis, we examined several forms of hippocampal LTP in wild-type and AC1 mutant mice. Wild-type and AC1 mutant mice exhibited comparable perforant path LTP recorded in the dentate gyrus as well as decremental LTP at the Schaffer

Long-term potentiation (LTP) in the hippocampus is a form of synaptic plasticity that may be an appropriate electrophysiological model for learning and memory (for review, see Siegelbaum and Kandel, 1991; Thompson, 1992; Malenka, 1994). Although the major synaptic pathways in the hippocampus, including the perforant, mossy fiber, and Schaffer collateral, all use excitatory amino acids as neurotransmitters and exhibit LTP, the mechanisms for LTP may be quite different (for review, see Nicoll and Malenka, 1995). For example, perforant path and the Schaffer collateral pathway LTP are both dependent on the activation of NMDA receptors (Bliss and Collingridge, 1993), whereas mossy fiber/CA3 LTP is not (Harris and Cotman, 1986; Zalutsky and Nicoll, 1990).

All forms of hippocampal LTP have a common requirement for increased intracellular $\mathrm{Ca}^{2+}$ initiated either postsynaptically through NMDA receptors or presynaptically through voltagesensitive $\mathrm{Ca}^{2+}$ channels (Kauer et al., 1988; Malenka et al., 1988; Nicoll et al., 1988). The mechanisms by which $\mathrm{Ca}^{2+}$ causes enhanced synaptic efficiency have not been fully defined; however, several kinases, including calmodulin-dependent protein kinases, PKC, MAP kinases, and PKA, have been implicated either in the initiation or in the maintenance of LTP (for review, see Suzuki, 1994). All of these protein kinase signaling pathways can be stimulated directly or indirectly by intracellular $\mathrm{Ca}^{2+}$.

There is increasing evidence that cAMP may play an important role in specific forms of hippocampal LTP. For example, cAMPmediated transcription is implicated in the late form of LTP in the Schaffer collateral, mossy fiber, and the medial perforant

\footnotetext{
Received Dec. 11, 1997; revised Jan. 30, 1998; accepted Feb. 20, 1998.

This research was supported by National Institutes of Health Grant 20498 to D.R.S.

E.C.V. and S.T.W. contributed equally to this manuscript.

Correspondence should be addressed to Dr. Storm at the above address.

Copyright (C) 1998 Society for Neuroscience $0270-6474 / 98 / 183186-09 \$ 05.00 / 0$
}

collateral $\rightarrow$ CA1 pyramidal cell synapse. Although the mutant mice exhibited normal paired pulse facilitation, mossy fiber LTP was impaired significantly in AC1 mutants. High concentrations of forskolin induced mossy fiber LTP to comparable levels in wild-type and AC1 mutant mice, indicating that signaling components downstream from the adenylyl cyclase, including PKA, ion channels, and secretory machinery, were not affected by disruption of the AC1 gene. These data indicate that coupling of $\mathrm{Ca}^{2+}$ to activation of AC1 is crucial for mossy fiber LTP, most likely via activation of PKA and enhancement of excitatory amino acid secretion.

Key words: adenylyl cyclase; mossy fiber LTP; cAMP; $\mathrm{Ca}^{2+}$; neuroplasticity; hippocampus

pathways (Frey et al., 1993; Impey et al., 1996; Abel et al., 1997). Because neurons of the hippocampus express $\mathrm{Ca}^{2+}$-stimulated adenylyl cyclases (Xia et al., 1991), increases in $\mathrm{Ca}^{2+}$ during LTP may elevate cAMP. Indeed, stimulation of NMDA receptors increases cAMP in area CA1 of the hippocampus (Chetkovich et al., 1991). Furthermore, LTP in both the dentate gyrus (Stanton and Sarvey, 1985b) and the CA1 (Chetkovich and Sweatt, 1993) increases cAMP.

In contrast to NMDA receptor-dependent LTP, which depends on increased postsynaptic $\mathrm{Ca}^{2+}$, mossy fiber LTP may require an increase in presynaptic $\mathrm{Ca}^{2+}$ (Zalutsky and Nicoll, 1990) (but see Jaffe and Johnston, 1990; Urban and Barrionuevo, 1996). Although mossy fiber LTP is dependent on increases in intracellular $\mathrm{Ca}^{2+}$ (Zalutsky and Nicoll, 1990; Johnston et al., 1992; Y. Y. Huang et al., 1994), the molecular mechanism for LTP at the mossy fiber $\rightarrow$ CA3 pyramidal cell synapse is not known. Evidence from several laboratories suggests that PKA activation is obligatory for the induction and maintenance of mossy fiber LTP (Y. Y. Huang et al., 1994; Weisskopf et al., 1994). For example, forskolin evokes LTP at the mossy fiber $\rightarrow$ CA3 synapse, whereas the inactive forskolin homolog, 1,9-dideoxy-forskolin, does not (Weisskopf et al., 1994), and mutant mice lacking PKA $\mathrm{C} 1 \beta$ or $\operatorname{Ri} \beta$ subunits are defective in mossy fiber LTP (Huang et al., 1995). Because agonists that stimulate adenylyl cyclases via receptor activation do not mimic mossy fiber LTP, it has been hypothesized that mossy fiber LTP is attributable to the stimulation of an adenylyl cyclase by presynaptic $\mathrm{Ca}^{2+}$ increases (Weisskopf et al., 1994).

Of the known adenylyl cyclases, only type 1 adenylyl cyclase (AC1) and type 8 adenylyl cyclase (AC8) are stimulated by $\mathrm{Ca}^{2+}$ and calmodulin $(\mathrm{CaM})$ in vivo. $\mathrm{AC1}$ is neurospecific and expressed in the dentate gyrus and the pyramidal cells in CA1, CA2, and CA3 layers of the hippocampus (Xia et al., 1991, 1993). To analyze the contribution of AC1 for synaptic plasticity, we dis- 
rupted the gene of $\mathrm{AC} 1$ in mice. We report that mutant mice lacking AC1 have normal perforant pathway and decremental CA1 LTP (D-LTP) but are deficient in mossy fiber LTP.

\section{MATERIALS AND METHODS}

Adenylyl cyclase activities in mutant mice. AC1 null mice (Wu et al., 1995) were back-crossed 12 generations into 129JR2448 mice to obtain mutant mice in a uniform genetic background. Wild-type mice from the same litters were used as controls. Hippocampal tissue from wild-type or AC1 mutant mice was suspended in homogenization buffer [containing (in mм) 20 Tris- $\mathrm{HCl}, \mathrm{pH} 7.4,0.5$ dithiothreitol, 1 EDTA, 1 EGTA, $2 \mathrm{MgCl}_{2}$, and 0.5 phenylmethylsulfonyl fluoride plus $5 \mathrm{mg} / \mathrm{ml}$ leupeptin] and homogenized at $4^{\circ} \mathrm{C}$. Unbroken cells and nuclei were removed by centrifugation at $600 \times g$ for $2 \mathrm{~min}$, and the supernatants were subjected to centrifugation at $30,000 \times g$ for $20 \mathrm{~min}$. The membrane pellet was suspended in the homogenization buffer without EGTA and assayed for adenylyl cyclase activity.

Adenylyl cyclase assays were performed at $30^{\circ} \mathrm{C}$ for $20 \mathrm{~min}$ by adding membrane fractions $(10-75 \mu \mathrm{g}$ of protein) to an assay solution containing (in mM) $1.0 \alpha\left[{ }^{32} \mathrm{P}\right]$ ATP $(500 \mathrm{cpm} / \mathrm{pmol}),{ }^{3}[\mathrm{H}]$ cyclic AMP $(20,000 \mathrm{cpm} /$ mmol), $5 \mathrm{MgCl}_{2}, 1$ EDTA, 2 cyclic AMP, 5 theophylline, and 20 creatine phosphate plus $0.1 \%$ bovine serum albumin, $1 \mu \mathrm{M} \mathrm{CaM}$, and $60 \mathrm{U} / \mathrm{ml}$ creatine phosphokinase in $20 \mathrm{~mm}$ Tris- $\mathrm{HCl}, \mathrm{pH} 7.4$, in a final assay volume of $250 \mu \mathrm{l}$. The reaction was stopped by adding $750 \mu \mathrm{l}$ of $1.5 \%$ sodium dodecyl sulfate. The reaction mixture was heated at $100^{\circ} \mathrm{C}$ for 2 min; the ${ }^{32}[\mathrm{P}]$-labeled and ${ }^{3}[\mathrm{H}]$-labeled cAMP that was generated was recovered by using Dowex AG-50 WX-4 and neutral alumina columns (Salomon et al., 1974). The values of adenylyl cyclase activities represent the mean of triplicate determinations $\pm \mathrm{SD}$. cAMP accumulation assays in cultured hippocampal neurons were performed as previously described (Reddy et al., 1995). Protein concentrations were determined with the Pierce BCA Protein Assay Kit (Rockford, IL). Free $\mathrm{Ca}^{2+}$ concentrations in the adenylyl cyclase buffers were varied using a $\mathrm{Ca}^{2+}$ / EGTA buffer system and were estimated using the Bound and Determined computer program (Brooks and Storey, 1992).

Primary hippocampal neuron cultures. Primary hippocampal neurons were established from postnatal day 1 mouse pups and maintained in defined medium with minimal supplements. Hippocampi were digested with $10 \mathrm{U} / \mathrm{ml}$ papain at $37^{\circ} \mathrm{C}$ for $20 \mathrm{~min}$. After two rinses the tissue was triturated in dissociation medium [containing (in $\mathrm{mm}$ ) $27 \mathrm{~K}_{2} \mathrm{SO}_{4}, 1$ kynurenic acid, $15 \mathrm{MgCl}_{2}, 74 \mathrm{Na}_{2} \mathrm{SO}_{4}, 18$ glucose, and 2 HEPES, $\mathrm{pH} 7.4$, plus $225 \mu \mathrm{M} \mathrm{CaCl}_{2}$ and $0.0012 \%$ phenol red), using a $5 \mathrm{ml}$ disposable plastic pipette. Ninety-six well plates were coated with poly-D-lysine (66 $\mu \mathrm{g} / \mathrm{ml}$ ). Cells were plated onto the inner 60 wells of the 96-well plates (the peripheral wells were filled with water to act as a humidity barrier) at $5 \times 10^{4}$ cells $/ \mathrm{cm}^{2}$ and maintained in Neurobasal Medium (Life Technologies, Gaithersburg, MD) in the presence of N-2 supplement (Bottenstein and Sato, 1979) with $10 \mathrm{U} / \mathrm{ml}$ penicillin, $10 \mu \mathrm{g} / \mathrm{ml}$ streptomycin, and $0.5 \mu \mathrm{g} / \mathrm{ml}$ glutamine for $10-16 \mathrm{~d}$ before use. Because Neurobasal Medium and N-2 did not maintain neuron viability for extended periods, the medium was modified. These modifications included the addition of $0.1 \%$ chicken ovalbumin (Sigma, St. Louis, MO) and increasing sodium selenite to at least $300 \mathrm{nM}$. cAMP accumulation in cultured neurons was measured two weeks after plating by the general method described in Nielsen et al., 1996.

Histology. Excised mouse brains from 8-week-old AC1 mutant and wild-type mice were soaked in $0.1 \%$ sodium sulfide in phosphate buffer for $1 \mathrm{hr}$, fixed in $4 \%$ paraformaldehyde overnight, and bathed in $30 \%$ sucrose buffer for $24 \mathrm{hr}$. Then the tissue was embedded in OCT (Miles, Elkhart, IN) and frozen in liquid nitrogen. Coronal sections $(40 \mu \mathrm{m})$ were cut in a sliding microtome. Sections were stained by the neo-Timm method (Holm and Geneser, 1991) and counterstained with neutral red or with cresyl violet.

Electrophysiology. Mice were killed by cervical dislocation, and the brains were removed quickly and placed in oxygenated Krebs'bicarbonate buffer [containing (in mM) $120 \mathrm{NaCl}, 3.5 \mathrm{KCl}, 1.3 \mathrm{MgCl}_{2}, 2.5$ $\mathrm{CaCl}_{2}, 1.25 \mathrm{NaH}_{2} \mathrm{PO}_{4}, 25.6 \mathrm{NaHCO}_{3}$, and 10 glucose, which was aerated with $95 \% \mathrm{O}_{2} / 5 \% \mathrm{CO}_{2}$ ]. Transverse hippocampal slices (400 $\mu \mathrm{m}$ thick) were prepared from wild-type or mutant mice (male or female, 8-12 weeks old) by using a Vibratome. Hippocampal slices were transferred to a submerged recording chamber containing oxygenated Krebs'bicarbonate buffer $\left(15-20^{\circ} \mathrm{C}\right)$. The Krebs'-bicarbonate buffer was perfused continuously through the chamber at a rate of $1-2 \mathrm{ml} / \mathrm{min}$. As the temperature in the recording chamber was increased slowly to $34^{\circ} \mathrm{C}$, the slices were allowed to recover for at least $1.5 \mathrm{hr}$ before beginning the electrophysiological experiments. A concentric tungsten bipolar stimulating electrode (100 $\mu \mathrm{m}$ in diameter; Rhodes Medical Supply) was used to stimulate Schaffer collateral afferent fibers in the stratum radiatum of the hippocampal CA1 region, stratum lucidum of the CA3 region, or perforant path fibers to evoke field EPSPs. To measure LTP in the dentate gyrus region, we prepared hippocampal slices as described above. A recording electrode was placed in the stratum granulosum of the dentate gyrus to record population spikes. Perforant path fibers were stimulated with an electrode placed in the outer two-thirds of the molecular layer, near the apex of the dentate gyrus. Synaptic responses were elicited at $0.02 \mathrm{~Hz}$, and the responses were recorded with microelectrodes (1-2 $\mu \mathrm{m}$ tip) filled with $3.0 \mathrm{~m} \mathrm{NaCl}$. Field EPSPs were recorded in the stratum radiatum of CA1 or stratum lucidum of CA3, and population spikes were recorded in stratum granulosum of the dentate gyrus, as previously described (Jin et al., 1997). To confirm that forskolin was readily removed by perfusion, we treated hippocampal slices with 50 $\mu \mathrm{M}$ forskolin for $10 \mathrm{~min}$ and then perfused them for $5 \mathrm{~min}$ with the Krebs'-bicarbonate buffer. Adenylyl cyclase activities measured in membrane preparations from the slice preparations before, immediately after exposure to forskolin, and $5 \mathrm{~min}$ after perfusion were $75 \pm 4,610 \pm 30$, and $69 \pm 6 \mathrm{pmol}$ of cAMP per minute per milligram, respectively. Test responses in the wild-type and $\mathrm{AC} 1$ mutant mice were the same amplitude, and care was taken that the stimulus and recording electrodes were in the same place for all slices. The experimenter who prepared the slices and did the LTP was blind as to the genotype of the mice.

\section{RESULTS}

\section{$\mathrm{Ca}^{2+}$ and forskolin-stimulated adenylyl cyclase activities in hippocampus from AC1 mutant mice}

The AC1 gene was disrupted in mice, as previously described, using 129JR2448 ES cells (Wu et al., 1995). Preliminary LTP studies using AC1 mutant and wild-type mice in a mixed BL6/129 genetic background showed considerable variation in electrophysiological responses within both populations. Because experiments using transgenic mice in a hybrid genetic background can lead to ambiguous results (Silva et al., 1997), the original AC1 mutant mouse strain, generated in a C57BL6/129JR2448 background, was back-crossed into a 129JR2448 background through 12 generations. Wild-type 129JR2448 mice were used as controls.

To verify that $\mathrm{Ca}^{2+}$-sensitive adenylyl cyclase activity was decreased in the hippocampus of the mutant mice after backcrossing into a 129JR2448 background, we assayed hippocampal membranes for $\mathrm{Ca}^{2+}$ - and forskolin-stimulated adenylyl cyclase activity (Fig. 1). $\mathrm{Ca}^{2+}$-stimulated and basal adenylyl cyclase activities in the hippocampus of $\mathrm{AC} 1$ mutant mice were both depressed $\sim 50 \%$ relative to wild-type mice (Fig. $1 A$ ). $\mathrm{Ca}^{2+}$. stimulated adenylyl cyclase activity also was decreased $50 \%$ in preparations obtained by dissection of the CA3 region of the hippocampus. For example, optimal $\mathrm{Ca}^{2+}$-stimulated adenylyl cyclase activities in these preparations were $475 \pm 20$ and $238 \pm$ 13 pmol cAMP per minute per milligram for wild-type and $\mathrm{AC} 1$ mutant mice, respectively. In addition, the $\mathrm{Ca}^{2+}$ sensitivity of the adenylyl cyclase in membranes from $\mathrm{AC} 1$ mutant mice was less than wild-type mice, consistent with $\mathrm{Ca}^{2+}$ activation of AC8 (Villacres et al., 1995). The wild-type hippocampus expresses nearly equivalent amounts of AC1 and AC8 mRNA (Villacres et al., 1995). Because $\mathrm{Ca}^{2+}$-stimulated adenylyl cyclase activity decreased $\sim 50 \%$ in $\mathrm{AC} 1$ mutant mice, the loss of $\mathrm{AC} 1$ apparently did not cause compensating increases in the expression of AC8 or other $\mathrm{Ca}^{2+}$-stimulated adenylyl cyclases. At forskolin concentrations in the range of $1-10 \mu \mathrm{M}$, forskolin-stimulated adenylyl cyclase activity was $\sim 50 \%$ lower in the mutants. However, $50 \mu \mathrm{M}$ forskolin stimulated hippocampal adenylyl cyclase to comparable levels in membranes from mutant and wild-type mice (Fig. 1B). This reflects the fact that several different forskolin-stimulated 

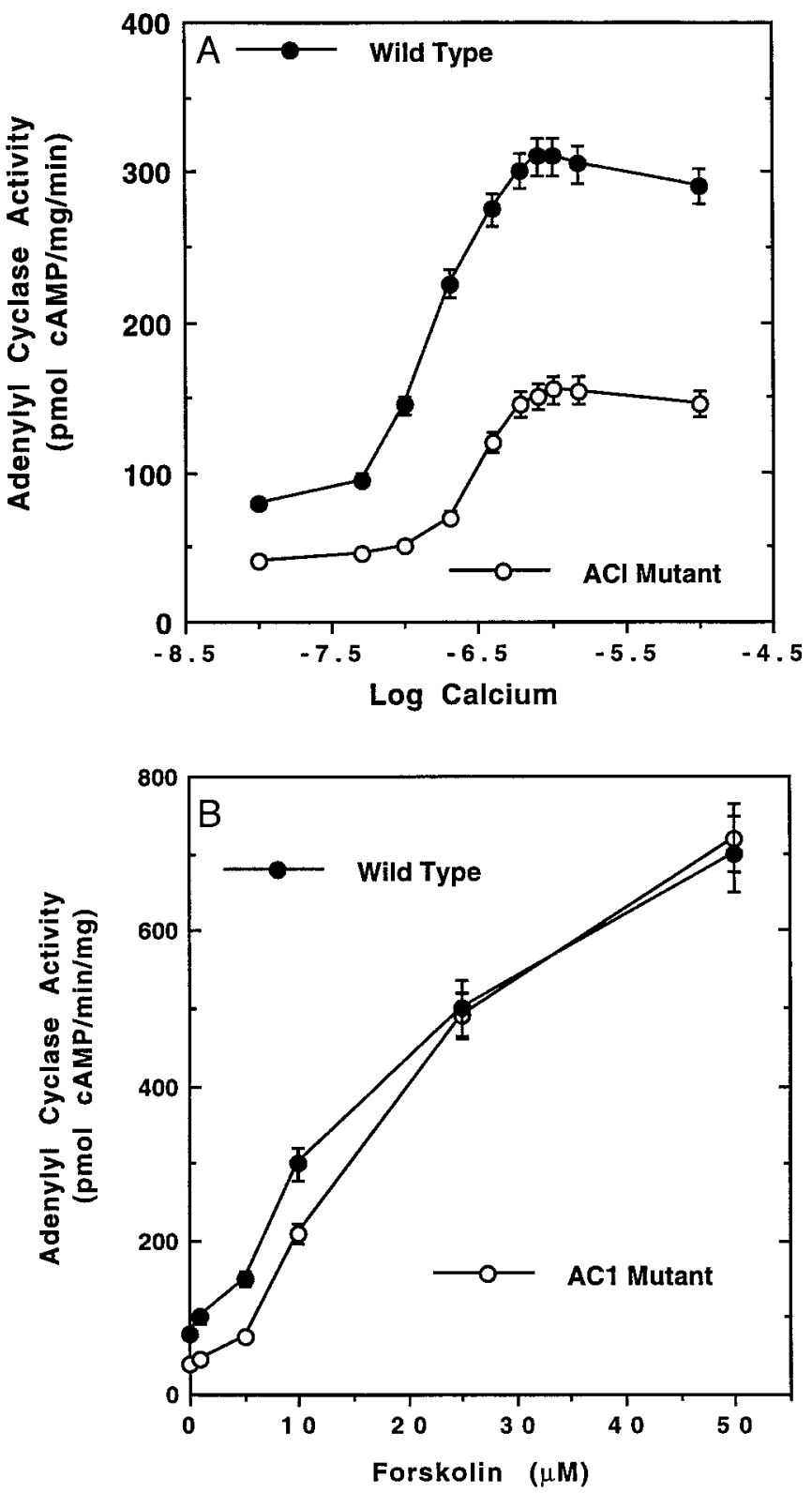

Figure 1. $\mathrm{Ca}^{2+}$ and forskolin-stimulated adenylyl cyclase activities in hippocampal membranes isolated from wild-type and AC1 mutant mice. $A, \mathrm{Ca}^{2+}$-stimulated adenylyl cyclase was assayed in hippocampal membranes in the presence of $2.4 \mu \mathrm{M} \mathrm{CaM}, 0.2 \mathrm{mM}$ EGTA, and varying levels of $\mathrm{CaCl}_{2}$, as described in Materials and Methods. $\mathrm{Ca}^{2+}$ stimulation of adenylyl cyclase was not observed when $\mathrm{CaM}$ was not included in the assays. B, Forskolin-stimulated adenylyl cyclase in hippocampal membranes from wild-type and AC1 mutant mice was measured as described in Materials and Methods.

adenylyl cyclases are expressed in the hippocampus; $50 \mu \mathrm{M}$ forskolin maximally stimulates adenylyl cyclases and obscures the ablation of AC1. In subsequent experiments, $50 \mu \mathrm{M}$ forskolin was used to generate equivalent cAMP signals in hippocampal slices from mutant and wild-type mice.

There was also a reduction in $\mathrm{Ca}^{2+}$-stimulated cAMP accumulation when cultured hippocampal neurons from the mutant and wild-type mice were assayed for intracellular cAMP in response to the $\mathrm{Ca}^{2+}$ ionophore $\mathrm{A} 23187$ (Fig. 2). This suggests that there were not other forms of biochemical compensation, e.g.,

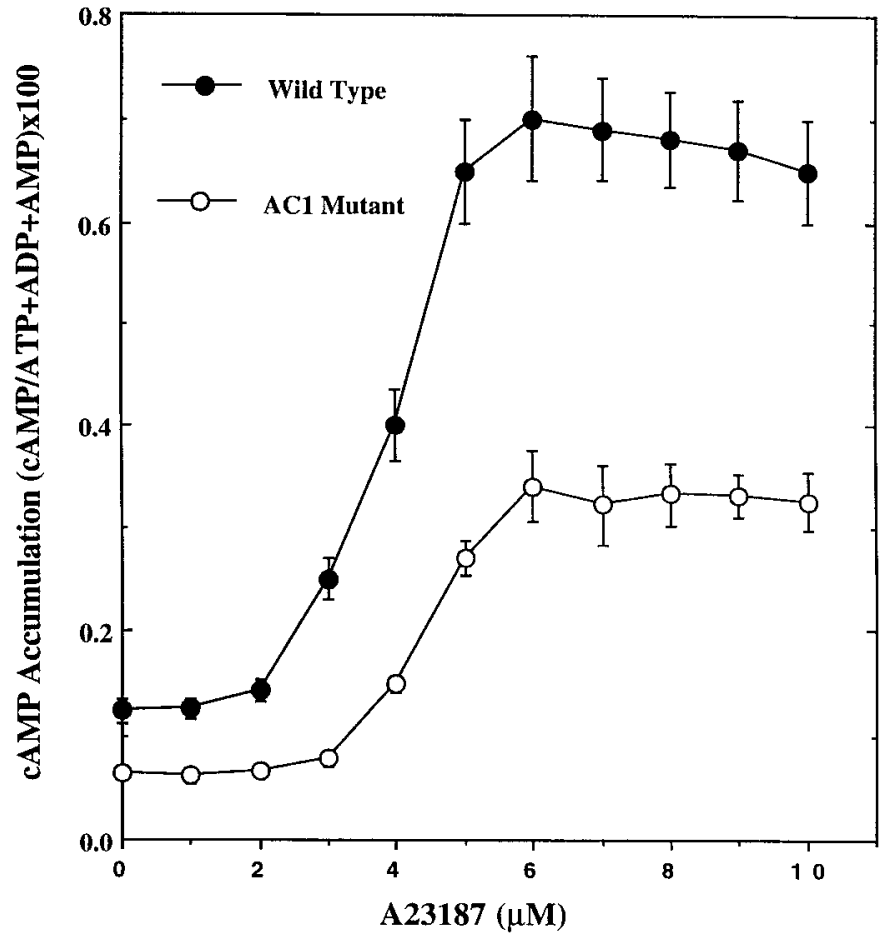

Figure 2. $\mathrm{Ca}^{2+}$ stimulation of cAMP accumulation in hippocampal neurons from wild-type and AC1 mutant mice. Hippocampal neurons were cultured as described in Materials and Methods. cAMP accumulation in the presence of $2 \mathrm{mM} \mathrm{CaCl}_{2}$ was determined as a function of the concentration of A23187, as described in Materials and Methods.

modification of cAMP transport or degradation mechanisms, to accommodate for the loss in AC1 activity.

\section{Hippocampal morphology is normal in AC1 mutant mice}

Because AC1 is expressed developmentally and reaches a maximum at postnatal day 16 (Villacres et al., 1995), we were concerned that the hippocampus of $\mathrm{AC} 1$ mutant mice might not develop normally. Therefore, brain coronal sections from wildtype and AC1 mutant mice were analyzed by staining with cresyl violet and Timm's stain (Fig. 3). The overall hippocampal morphologies of wild-type and AC1 mutant mice were indistinguishable (Fig. $3 A, B$ ), and there were no apparent differences in cell body density in the CA1-CA3 pyramidal or granule cells (Fig. $3 C, D)$. Hippocampal slices also were stained with Timm's stain, which strongly stains the mossy fiber pathway (Fig. $3 E, F$ ). The Timm stain also revealed no anatomical differences in the mossy fiber tract. This is consistent with data, discussed below, showing normal synaptic transmission and paired pulse facilitation at the mossy fiber synapse as well as normal perforant path and CA1 D-LTP.

\section{AC1 mutant mice exhibit normal perforant pathway LTP}

The perforant pathway, from the pyramidal cells in the entorhinal area to the granule cells of the dentate gyrus, exhibits NMDAdependent LTP (Bliss and Collingridge, 1993). Although the mechanism for induction and maintenance of perforant path LTP is not known, the $\beta$-adrenergic antagonist propranolol blocks LTP induction (Bramham et al., 1997), and the $\beta$-adrenergic agonist norepinephrine (NE) induces LTP in the perforant path input to dentate granule cells (Harley, 1991). High-frequency 

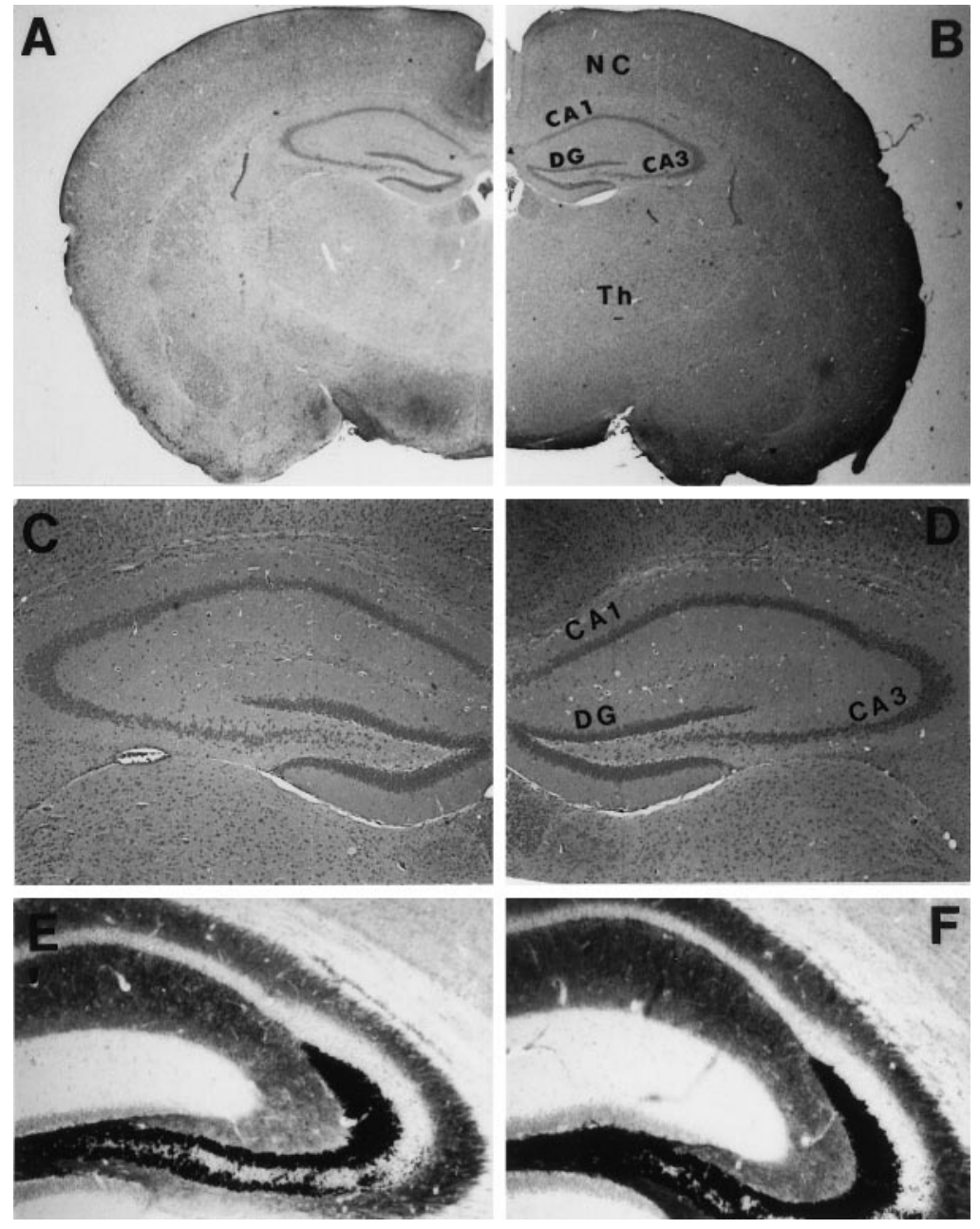

Figure 3. Cresyl violet and Timm stain of the hippocampus from wild-type and AC1 mutant mice. Shown are coronal sections of cresyl violet-stained $(A)$ wild-type and $(B)$ mutant mouse brains and coronal sections of cresyl violetstained $(C)$ wild-type and $(D)$ mutant mouse brains. Comparison of the mossy fibers (the most intense black section) between the wild-type $(E)$ and the AC1 mutant mice $(F)$ showed no differences. stimulation of the perforant pathway increases cAMP, which is abolished on depletion of norepinephrine NE (Stanton and Sarvey, 1985a). Furthermore, forskolin enhances NE-induced potentiation (Stanton and Sarvey, 1985b). This suggests that adenylyl cyclase activation contributes to perforant pathway LTP and NE-induced LTP in the dentate gyrus. Because an increase in $\mathrm{Ca}^{2+}$ resulting from depolarization of the postsynaptic granule cell is critical for perforant pathway LTP, $\mathrm{Ca}^{2+}$-stimulated adenylyl cyclases may contribute to perforant pathway LTP by coupling $\mathrm{Ca}^{2+}$ to cAMP increases. However, perforant pathway LTP in AC1 mutant and wild-type mice was indistinguishable (Fig. 4). Three high-frequency trains $(100 \mathrm{~Hz}$ for $0.1 \mathrm{sec}, 0.3 \mathrm{msec}$ pulse duration repeated at $10 \mathrm{sec}$ intervals) applied to the perforant pathway induced robust LTP in both the wild-type mice $(201 \pm 14 \%, 60 \mathrm{~min}$ after tetanus) and in mutant mice (201 \pm $26 \%, 60$ min after tetanus). These data indicate that AC1 is not critical for perforant path LTP, and AC1 mutant mice are not generally deficient in synaptic transmission or hippocampal LTP.

\section{Schaffer collateral D-LTP is normal in AC1 mutant mice}

Two forms of LTP can be distinguished at the Schaffer collateral $\rightarrow$ CA1 pyramidal cell synapse: an early form of LTP, lasting $<3 \mathrm{hr}$, and long-lasting LTP (L-LTP), persisting $>3 \mathrm{hr}$ (Frey et al., 1991, 1993; Impey et al., 1996; Frey and Morris, 1997). The early phase of LTP or D-LTP can be generated by a single high-frequency stimulus and requires the activation of protein kinases. The late phase of LTP or L-LTP is generated by multiple trains of high-frequency stimulation, can last hours or even days, and is sensitive to inhibitors of transcription and translation (Frey et al., 1993; Nguyen et al., 1994). cAMP has been shown to play a role in both D-LTP and L-LTP (Frey et al., 1993; Nguyen et al., 1994). However, cAMP is required for the induction of L-LTP, but not D-LTP (Blitzer et al., 1995; Thomas et al., 1996). One high-frequency train $(100 \mathrm{~Hz}$ for $1 \mathrm{sec}, 0.15$ msec pulse duration) elicited robust LTP in wild-type and mutant mice, which decayed within $3 \mathrm{hr}$. Although there was a slight depression in D-LTP measured in AC1 mutant mice when compared with wild-type mice, the difference was not statistically significant (Fig. 5). In contrast, L-LTP, which is generated by a different stimulus protocol, was depressed significantly, but not abrogated, in AC1 mutant mice (Wu et al., 1995).

\section{Mossy fiber LTP is depressed in AC1 mutant mice}

Mossy fiber pathway LTP was induced by four high-frequency trains $(100 \mathrm{~Hz}$ for $1 \mathrm{sec}, 0.3 \mathrm{msec}$, pulse duration repeated at 20 sec intervals) in the presence of the NMDA inhibitor 2-amino5-phosphonopentanoic acid (APV). Hippocampal slices from wild-type mice showed mossy fiber LTP comparable to that reported in previous studies (Huang et al., 1995). However, there was a significant impairment of mossy fiber LTP in AC1 mutants, as compared with that in wild-type mice (Fig. 6). The maximum change elicited in wild-type mice was $242 \% \pm 20 \%$, whereas the mutant maximum was $144 \% \pm 10 \%$. A study of nine slices from seven different wild-type mice showed robust LTP (average = 
Figure 4. Perforant path LTP in wildtype and AC1 mutant mice. LTP was induced by tetanic stimulation consisting of $100 \mathrm{msec}$ trains at $100 \mathrm{~Hz}$ given every 10 $\mathrm{sec}$ for three times. Bicuculline $(50 \mu \mathrm{M})$ was added to the perfusate at least $20 \mathrm{~min}$ before recording and delivered throughout each experiment. The reported data are averages from eight wild-type and eight AC1 mutant mice.
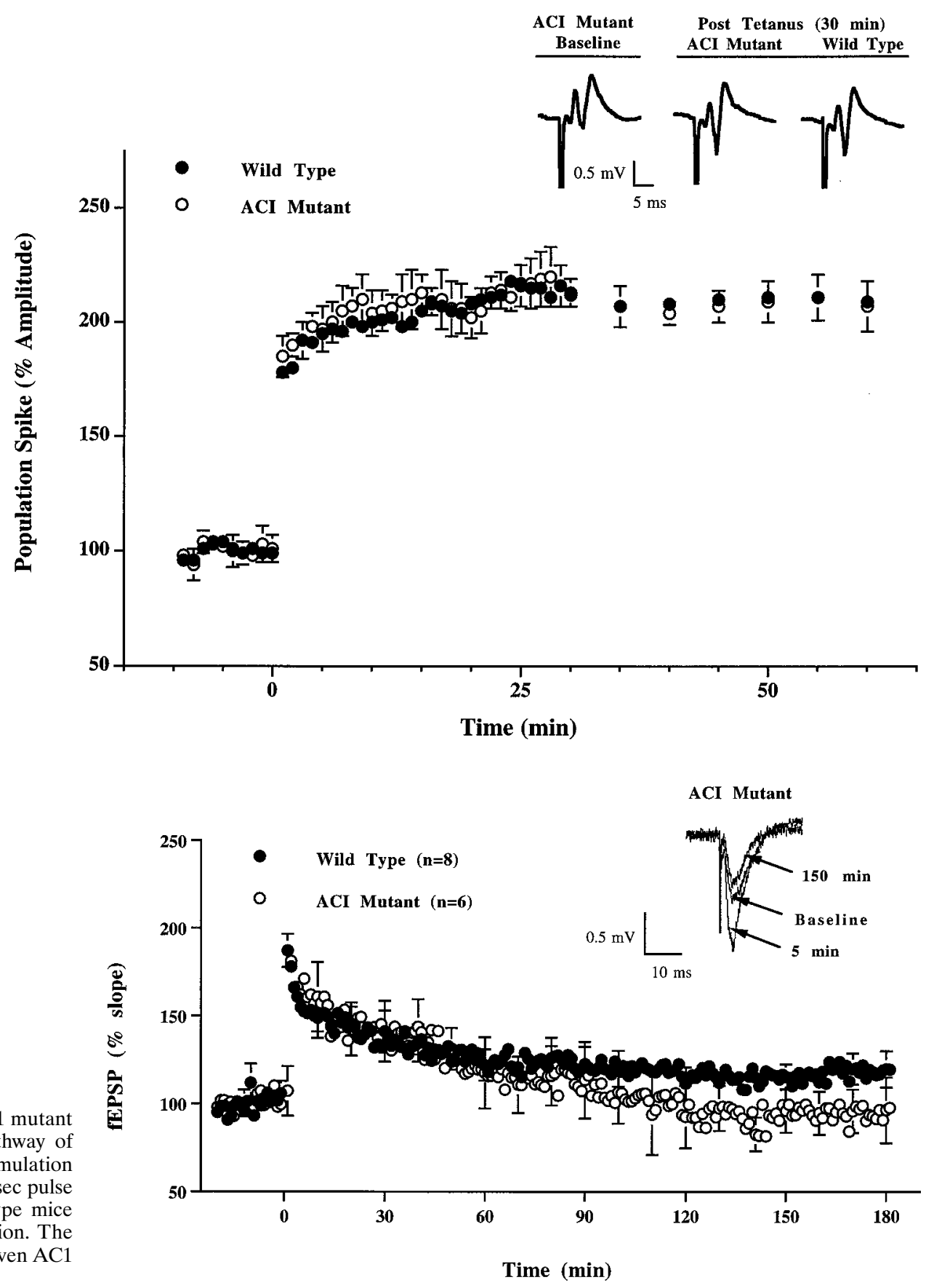

Figure 5. CA1 D-LTP in wild-type and AC1 mutant mice. D-LTP in the Schaffer collateral pathway of mutant mice was induced by a tetanic stimulation consisting of a $1 \mathrm{sec}$ train at $100 \mathrm{~Hz}$ at $15 \mathrm{msec}$ pulse duration. D-LTP in the mutant and wild-type mice decayed within $3 \mathrm{hr}$ of post-tetanic stimulation. The data show averages from six wild-type and seven AC1 mutant mice. examined PPF in AC1 mutant and wild-type mice at the mossy fiber synapse. PPF was indistinguishable in wild-type and AC1 mutant mice (Fig. 7). In both cases PPF was maximal when the interpulse interval was 30-50 msec and was essentially absent at interpulse intervals of $150-200 \mathrm{msec}$. This indicates that presynaptic neurotransmitter release responds normally to activation of the synapse by short-interval paired pulses in mutant mice. This is consistent with previous data showing that $\mathrm{PKA}\left(\mathrm{Cb}_{1}\right.$ isoform $)$ mutant mice show normal PPF but impaired mossy fiber LTP (Huang et al., 1995).

\section{AC1 mutant mice show a normal response to forskolin}

The deficiency in mossy fiber LTP described above may reflect a direct role of AC1 in mossy fiber LTP or indirect changes in

downstream components of the signal transduction pathway. To crease in neurotransmitter release (Salin et al., 1996b). Because AC1 mutant mice might have a deficit in transmitter release, we 


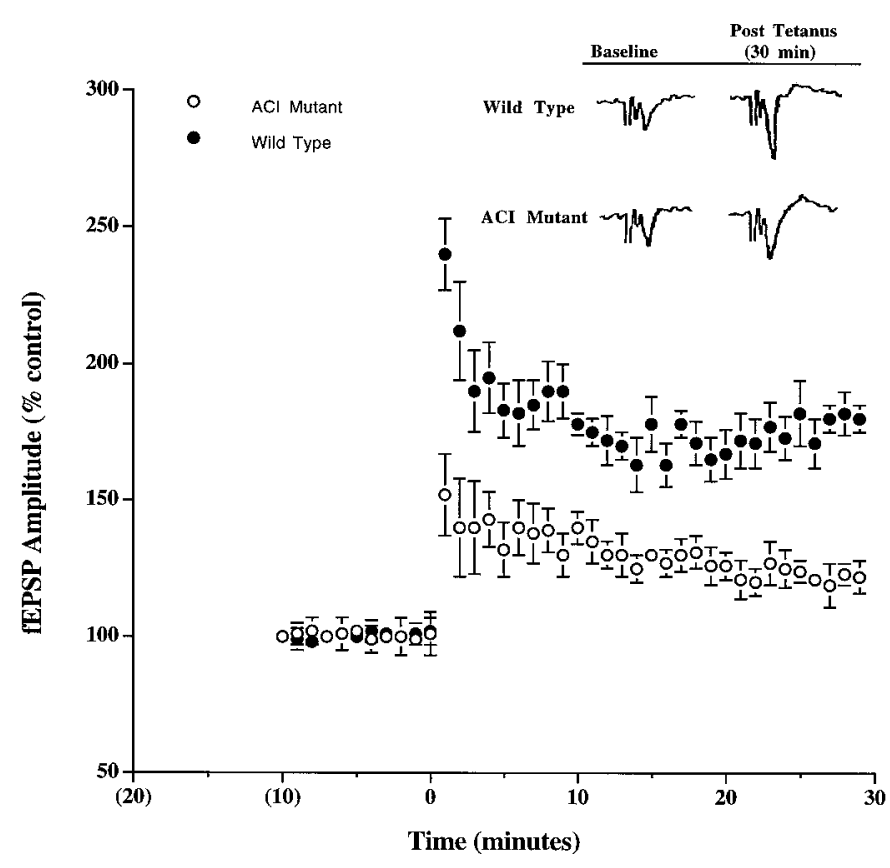

Figure 6. Mossy fiber LTP in AC1 mutant and wild-type mice. LTP was induced in the mossy fiber pathway of mutant and wild-type mice by tetanic stimulation consisting of $1 \mathrm{sec}$ trains at $100 \mathrm{~Hz}$, given four times, with a $20 \mathrm{sec}$ interval between trains. D-2-Amino-5-phosphonovaleric acid (APV; $50 \mu \mathrm{M}$ ) was perfused during tetanic stimulation to block NMDA receptors. Nine slices from seven different wild-type mice showed robust LTP, whereas seven slices from six different AC1 mutant mice showed substantially decreased LTP.

address this issue, we examined the effect of forskolin on synaptic activity, using hippocampal slices from wild-type and AC1 mutant mice. Application of forskolin induces long-lasting potentiation at the mossy fiber synapse and occludes LTP generated by tetanic stimulation. The potentiation caused by forskolin is blocked by inhibitors of PKA (Y. Y. Huang et al., 1994; Weisskopf et al., 1994). Because $50 \mu \mathrm{M}$ forskolin stimulated adenylyl cyclase activities to comparable levels in membranes from wildtype and AC1 mutant mice (see Fig. $1 B$ ), hippocampal slices were treated with $50 \mu \mathrm{M}$ forskolin, and synaptic potentiation was recorded (Fig. 8). Forskolin elicited a similar response in wild-type and mutant AC1 slices. In both cases field EPSP increased 190$200 \%$, and there was no difference in response between wild-type and mutant mice. This indicates that the disruption of the AC1 gene does not lead to defects in signal transduction components downstream from AC1.

\section{DISCUSSION}

Mossy fiber LTP is ablated by PKA inhibitors, including Rp-cAMPs as well as KT5720, and treatment of hippocampal slices with forskolin produces long-lasting potentiation (Y. Y. Huang et al., 1994; Weisskopf et al., 1994). These and other observations suggest that activation of one or more adenylyl cyclases may be crucial for the induction and maintenance of mossy fiber LTP. The neurospecific expression of AC1 and its distribution in brain are consistent with the proposal that this enzyme may be important for some forms of synaptic plasticity (Xia et al., 1991, 1995). AC1 is stimulated directly by $\mathrm{Ca}^{2+}$ and CaM in vivo (Choi et al., 1992; Wu et al., 1993), with halfmaximal stimulation at $200 \mathrm{nM}$ free $\mathrm{Ca}^{2+}$. Although $\mathrm{AC} 1$ is not stimulated by $\mathrm{G}_{\mathrm{s}}$-coupled receptors alone, it is stimulated by

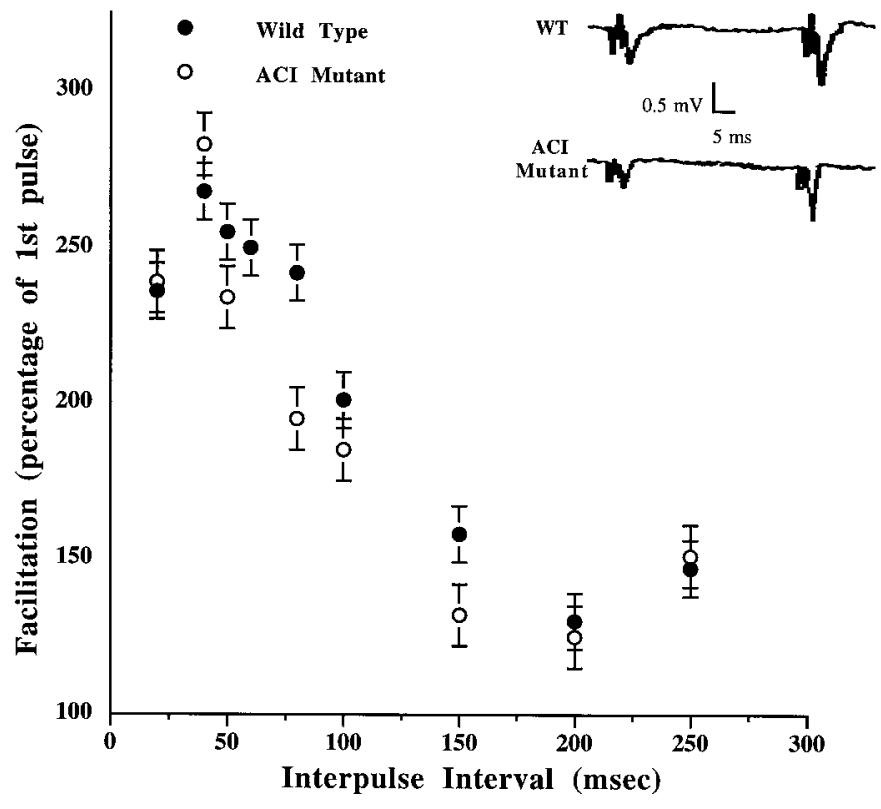

Figure 7. Paired pulse facilitation at the mossy fiber $\rightarrow$ CA3 synapse. Paired pulse facilitation was examined by applying two pulses separated by intervals of 20-250 msec. The ratio of the slope of the second EPSP to the first EPSP was plotted as a function of the pulse interval. A comparison of paired pulse facilitation between AC1 mutant and wild-type mice showed no significant difference (mean $\pm \mathrm{SEM}, n=16$ ).

receptor activation when it is paired with $\mathrm{Ca}^{2+}$ (Wayman et al., 1994). Consequently, AC1 can function as a coincidence detector and generate cAMP increases greater than that produced by $\mathrm{Ca}^{2+}$ or neurotransmitters alone. AC8 also is expressed in various areas of the hippocampus, including CA1-CA3 pyramidal cells as well as granule cells in the dentate gyrus (Cali et al., 1994). The $\mathrm{Ca}^{2+}$ sensitivity of AC8 is approximately five times lower than AC1 (Villacres et al., 1995), and it is not stimulated by $\mathrm{G}_{\mathrm{s}}$-coupled receptors, even in the presence of $\mathrm{Ca}^{2+}$ (Nielsen et al., 1996). On the basis of regulatory properties, AC1 is the most likely candidate for the generation of cAMP signals during mossy fiber LTP (for review, see Xia and Storm, 1997). The objective of this study was to evaluate the role of AC1 for mossy fiber LTP, using a mouse strain lacking AC1.

Occasionally, disruption of one gene in multigene families can result in compensating increases in other members of the same family. For example, mutant mice lacking the R1 $\beta$ subunit of PKA show a compensating increase in the R1 $\alpha$ subunit (Brandon et al., 1995). Isozyme compensation complicates the interpretation of data obtained with the $\operatorname{Ri} \beta$ mutant, particularly because the mutant mice show no decrease in total PKA activity. $\mathrm{Ca}^{2+}$ stimulated adenylyl cyclase activity in the hippocampus of $\mathrm{AC} 1$ mutant mice was reduced $\sim 50 \%$, as compared with wild-type mice in the same genetic background. The residual $\mathrm{Ca}^{2+}$. stimulated adenylyl cyclase activity in $\mathrm{AC} 1$ mutant mice was less sensitive to $\mathrm{Ca}^{2+}$ and consistent with the $\mathrm{Ca}^{2+}$ sensitivity of AC8. This indicates that there were not compensating increases in the expression of AC8 or other adenylyl cyclases to restore $\mathrm{Ca}^{2+}$-stimulated adenylyl cyclase activity to wild-type levels. Furthermore, $\mathrm{Ca}^{2+}$ stimulation of cAMP accumulation in cultured hippocampal neurons also was reduced $\sim 50 \%$ in the mutant mice, indicating that other biochemical changes did not compensate for the deficit in the coupling of intracellular $\mathrm{Ca}^{2+}$ to cAMP increases. 


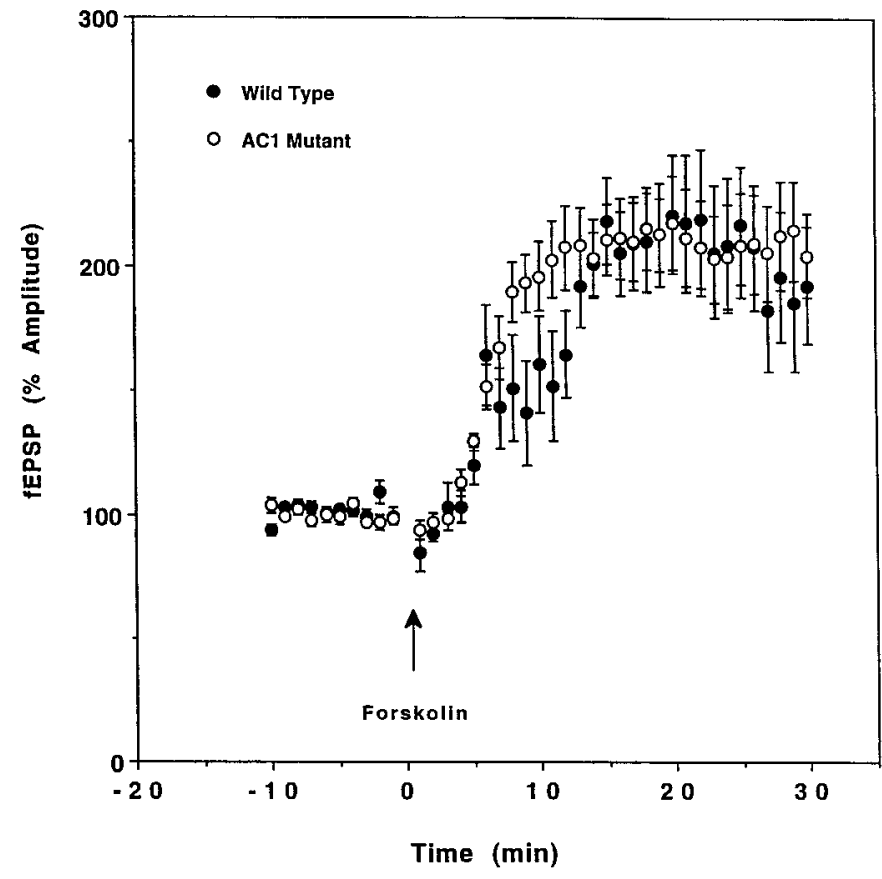

Figure 8. Forskolin-induced LTP at the mossy fiber $\rightarrow$ CA3 pyramidal cell synapse. Hippocampal slices were perfused with (in $\mu \mathrm{M}$ ) 50 forskolin, $100 \mathrm{IBMX}$, and $50 \mathrm{APV}$ for $30 \mathrm{~min}$. APV was perfused $15 \mathrm{~min}$ before forskolin. Forskolin-induced potentiation was comparable in wild-type and $\mathrm{AC} 1$ mutant mice.

Disruption of specific genes can lead to developmental deficiencies that cause general impairment of physiological functions and compromises interpretation of the data. We were concerned that the brains of AC1 mutant mice might develop abnormally because $\mathrm{Ca}^{2+}$-stimulated adenylyl cyclase activity in the hippocampus of mice and rats increases between postnatal days 1 and 14. This increase is attributable primarily to the increased expression of AC1 (Villacres et al., 1995). Therefore, the morphology of the hippocampus and the mossy fiber tract in mutant mice was examined to determine whether hippocampal development was affected by ablation of the AC1 gene. This analysis showed no gross anatomical differences in the hippocampus from wild-type and AC1 mutant mice. There were also no apparent differences in the arrangement of cell body layers in the hippocampus when the sections were examined at higher magnification. An analysis of primary cultured hippocampal neurons prepared from the hippocampi of ACI mutant and wild-type mice by light microscopy showed no apparent differences in cell morphology, size, or pattern of neurite outgrowth (data not shown). This suggests that AC1 is not crucial for the development of the hippocampus, although it may be important for some forms of synaptic plasticity.

An examination of several forms of LTP in AC1 mutant mice, including perforant path and D-LTP at the Schaffer collateral synapse, showed no serious impairment in AC1 mutant mice. The mutants also were able to generate sustained CA1 L-LTP (Wu et al., 1995), although CA1 D-LTP and the early phases of L-LTP were depressed somewhat, as compared with those of wild-type mice. Furthermore, LTD in the cerebellum was also normal in AC1 mutants (Linden and D. Storm, unpublished observations). In contrast, mossy fiber LTP was reduced significantly in AC1 mutant mice, suggesting that AC1 may be important for this LTP.
There are several possible explanations for the residual mossy fiber LTP in AC1 mutant mice. Because AC8 is expressed in the hippocampus (Cali et al., 1994; Villacres et al., 1995), AC8 may be responsible for this remaining LTP. Alternatively, the postsynaptic form of mossy fiber LTP described by Jaffe and Johnson (1990) may not depend on AC1.

What is the molecular role for AC1 in mossy fiber LTP? AC1 has two unique regulatory properties that may contribute to synaptic plasticity at the mossy fiber synapse. It is stimulated by free $\mathrm{Ca}^{2+}$ as low as 150-200 nu (Choi et al., 1992; Villacres et al., 1995) and synergistically stimulated by $\mathrm{Ca}^{2+}$ and $\mathrm{G}_{\mathrm{s}}$-coupled receptors (Wayman et al., 1994). Consequently, AC1 is poised to respond to presynaptic $\mathrm{Ca}^{2+}$ increases. We hypothesize that increases in presynaptic $\mathrm{Ca}^{2+}$ stimulate $\mathrm{AC} 1$ and lead to elevated cAMP and the activation of PKA. The mechanism by which PKA activation causes a persistent increase in glutamate release is not known, but it may be attributable to direct phosphorylation of one or more proteins in the secretory machinery (Trudeau et al., 1996). A likely candidate is Rab3A, a PKA substrate that may contribute to PKA-mediated neurotransmitter release by regulating $\mathrm{Ca}^{2+}$-stimulated vesicle release (Geppert et al., 1997). Interestingly, Rab3A mutant mice exhibit normal short-term plasticities but lack mossy fiber LTP (Castillo et al., 1997). Because there are noradrenergic projections from the locus ceruleus to the dentate gyrus and to the stratum lucidum of the CA3 where the glutamatergic mossy fibers terminate, modulation of mossy fiber LTP by $\beta$-adrenergic input (Huang and Kandel, 1996) may be attributable to synergistic stimulation of $\mathrm{AC} 1$ by $\beta$-adrenergic receptors and $\mathrm{Ca}^{2+}$.

The LTP mechanism described above may not be unique to the mossy fiber $\rightarrow$ CA3 synapse. AC1 is expressed at relatively high levels in dentate granule cells of the hippocampus as well as cerebellar granule cells (Xia et al., 1991). Cerebellar parallel fibers exhibit an LTP with properties similar to hippocampal mossy fiber LTP (Salin et al., 1996a). Cerebellar LTP is independent of NMDA receptors but dependent on extracellular $\mathrm{Ca}^{2+}$ and adenylyl cyclase activation. Interestingly, AC1 mutant mice show a number of defects in cerebellar physiology, including the lack of parallel fiber/Purkinje cell LTP in dissociated neuron cultures (D. Linden and D. Storm, unpublished observations).

AC1 mutant mice are deficient in spatial memory, as measured by the Morris water task (Wu et al., 1995). The mutant mice learn to find the visible and hidden platform normally, but they fail the transfer test and do not display a preference for the site where the platform had been before it was removed. Is there any relationship between this defect in spatial learning and impaired mossy fiber LTP? Although the hippocampus circuitry is thought to be crucial for learning and the formation of some types of memory (Scoville and Milner, 1957), the relationship between specific forms of LTP and spatial memory is controversial (for review, see Jeffery, 1997). Mossy fiber LTP may be important for memory because it is a crucial relay within hippocampal circuitry (Buckmaster and Schwartzkroin, 1994), and it may be a signal amplifier for the medial temporal memory system (Treves and Rolls, 1992). There are several lines of evidence supporting a critical role of the mossy fiber $\rightarrow$ CA3 pyramidal synapse in learning and memory. For example, the firing pattern in CA3 pyramidal neurons and dentate gyrus granule cells measured in moving rats, while the animals perform a spatial memory task, is similar (Jung and McNaughton, 1993). This suggests that one of the major inputs to CA3 pyramidal cells is from granule cells of the dentate gyrus. There is also a corre- 
lation between the size of the hippocampal mossy fiber terminal fields and several forms of spatial learning; mice with larger mossy fiber fields learn spatial tasks better and habituate more rapidly in open fields (Crusio et al., 1987, 1989; Schwegler et al., 1988). Furthermore, damage of the CA3 region or removal of granule cells impairs spatial learning in the Morris water task (Sutherland et al., 1983; McNaughton et al., 1989). The deficiencies in spatial memory and mossy fiber LTP observed with the AC1 mutant mice are consistent with the hypothesis that the mossy fiber LTP may be a useful electrophysiological model for spatial memory. However, the AC1 mutant mice also show impaired L-LTP and depressed D-LTP in the CA1. Consequently, it is not possible to make any conclusions concerning the relationship between these forms of LTP and spatial memory.

In summary, disruption of the gene for AC1 caused a strikingly selective defect in mossy fiber LTP in the hippocampus without seriously affecting NMDA-dependent forms of LTP in the perforant pathway or at the Schaffer collateral $\rightarrow$ CA1 pyramidal cell synapse. These data indicate that the coupling of $\mathrm{Ca}^{2+}$ increases to $\mathrm{cAMP}$ via activation of $\mathrm{AC} 1$ is critical for full expression of mossy fiber LTP.

\section{REFERENCES}

Abel T, Nguyen PV, Barad M, Deuel TAS, Kandel ER (1997) Genetic demonstration of a role for PKA in the late phase of LTP and in hippocampus-based long-term memory. Cell 88:615-626.

Bliss TVP, Collingridge GL (1993) A synaptic model of memory: longterm potentiation in the hippocampus. Nature 361:31-39.

Blitzer RD, Wong T, Nouranifar R, Iyengar R, Landau EM (1995) Postsynaptic cAMP pathway gates early LTP in hippocampal CA1 region. Neuron 15:1403-1414.

Bottenstein JE, Sato GH (1979) Growth of a rat neuroblastoma cell line in serum-free supplemented medium. Proc Natl Acad Sci USA 70:514-519.

Bramham CR, Bacher-Svendsen K, Sarvey JM (1997) LTP in the lateral perforant path is $\beta$-adrenergic receptor-dependent. NeuroReport 8:719-724.

Brandon EP, Zhuo M, Huang YY, Qi M, Gerhold KA, Burton KA, Kandel ER, McKnight GS, Idzerda RL (1995) Hippocampal longterm depression and depotentiation are defective in mice carrying a targeted disruption of the gene encoding the RI $\beta$-subunit of cAMPdependent protein kinase. Proc Natl Acad Sci USA 92:8851-8855.

Brooks SPJ, Storey KB (1992) Bound and determined: a computer program for making buffers of defined ion concentrations. Biochemistry 201:119-126.

Buckmaster PS, Schwartzkroin PA (1994) Hippocampal mossy cell function: a speculative view. Hippocampus 4:393-402.

Cali JJ, Zwaagstra C, Mons N, Cooper DMF, Krupinski J (1994) Type VIII adenylyl cyclase: a $\mathrm{Ca}^{2+} /$ calmodulin-stimulated enzyme expressed in discrete regions of rat brain. J Biol Chem 269:12190-12196.

Castillo PE, Janz R, Sudhof TC, Tzounopoulos T, Malenka RC, Nicoll RA (1997) Rab3A is essential for mossy fiber long-term potentiation in the hippocampus. Nature 388:590-593.

Chetkovich DM, Sweatt JD (1993) NMDA receptor activation increases cAMP in area CA1 of the hippocampus via calcium/calmodulin stimulation of adenylyl cyclase. J Neurochem 61:1933-1942.

Chetkovich DM, Gray R, Sweatt JDD (1991) $N$-methyl-D-aspartate receptor activation increases cAMP levels and voltage-gated $\mathrm{Ca}^{2+}$ channel activity in area CA1 of hippocampus. Proc Natl Acad Sci USA 88:6467-6471.

Choi EJ, Wong ST, Hinds TR, Storm DR (1992) $\mathrm{Ca}^{2+}$ and muscarinic agonist stimulation of type I adenylyl cyclase in whole cells. J Biol Chem 267:12440-12442.

Crusio WE, Schwegler H, Lipp HP (1987) Radial maze performance and structural variation of the hippocampus in mice: a correlation with mossy fiber distribution. Brain Res 425:182-185.

Crusio WE, Schwegler H, van Abeelen JH (1989) Behavioral responses to novelty and structural variation of the hippocampus in mice. II. Multivariate genetic analysis. Behav Brain Res 32:81-88.
Frey U, Morris RGM (1997) Synaptic tagging and long-term potentiation. Nature 385:533-536.

Frey U, Reymann KG, Matthies H (1991) The effect of dopaminergic D1 receptor blockade during tetanization on the expression of long-term potentiation in the rat CA1 region in vitro. Neurosci Lett 129:111-114.

Frey U, Huang YY, Kandel ER (1993) Effects of cAMP simulate a late stage of LTP in hippocampal CA1 neurons. Science 260:1661-1664.

Geppert M, Goda Y, Stevens CF, Sudhof TC (1997) Rab3A regulates a late step in synaptic vesicle fusion. Nature 387:810-814.

Harley C (1991) Noradrenergic and locus coeruleus modulation of the perforant path-evoked potential in rat dentate gyrus supports a role for the locus coeruleus in attentional and memorial processes. Prog Brain Res 88:307-321.

Harris EW, Cotman CW (1986) Long-term potentiation of guinea pig mossy fiber responses is not blocked by $N$-methyl-D-aspartate antagonists. Neurosci Lett 70:132-137.

Holm IA, Geneser FA (1991) Histochemical demonstration of zinc in the hippocampal region of the domestic pig: the dentate area. J Comp Neurol 308:409-417.

Huang D, Shipman-Appasamy PM, Orten DJ, Hinrichs SH, Prystowsky MB (1994) Promoter activity of the proliferating-cell nuclear antigen gene is associated with inducible CRE-binding proteins in interleukin 2-stimulated T-lymphocytes. Mol Cell Biol 14:4233-4243.

Huang YY, Kandel R (1996) Modulation of both the early and the late phase of mossy fiber LTP by the activation of $\beta$-adrenergic receptors. Neuron 16:611-617.

Huang YY, Li XC, Kandel ER (1994) cAMP contributes to mossy fiber LTP by initiating both a covalently mediated early phase and macromolecular synthesis-dependent late phase. Cell 79:69-79.

Huang YY, Kandel ER, Varshavsky L, Brandon EP, Qi M, Idzerda RL, McKnight GS, Bourtchouladze R (1995) A genetic test of the effects of mutations in PKA on mossy fiber LTP and its relation to spatial and contextual learning. Cell 83:1211-1222.

Impey S, Mark M, Villacres EC, Poser S, Chavkin C, Storm DR (1996) Induction of CRE-mediated gene expression by stimuli that generate long-lasting LTP in area CA1 of the hippocampus. Neuron 16:973-982.

Jaffe D, Johnston D (1990) Induction of long-term potentiation at hippocampal mossy fiber synapses follows a Hebbian rule. J Neurophysiol 64:948-960.

Jeffery KJ (1997) LTP and spatial learning—where to next? Hippocampus 7:95-110.

Jin WZ, Terman GW, Chavkin C (1997) Kappa opioid receptor tolerance in the guinea pig hippocampus. J Pharmacol Exp Ther 281:123-128.

Johnston D, Williams S, Jaffee D, Gray R (1992) NMDA-receptorindependent long-term potentiation. Annu Rev Physiol 54:489-505.

Jung MW, McNaughton BL (1993) Spatial selectivity of unit activity in the hippocampal granular layer. Hippocampus 3:165-182.

Kauer JA, Malenka RC, Nicoll RA (1988) NMDA application potentiates synaptic transmission in the hippocampus. Nature 334:250-252.

Malenka RC (1994) Synaptic plasticity in the hippocampus: LTP and LTD. Cell 78:535-538.

Malenka RC, Kauer JA, Zucker RS, Nicoll RA (1988) Postsynaptic $\mathrm{Ca}^{2+}$ is sufficient for potentiation of hippocampal synaptic transmission. Science 242:81-84.

McNaughton BL, Barnes CA, Meltzer J, Sutherland RJ (1989) Hippocampal granule cells are necessary for normal spatial learning but not for spatially selective pyramidal cell discharge. Exp Brain Res 76:485-496.

Nguyen PV, Abel T, Kandel ER (1994) Requirement of a critical period of transcription for induction of a late phase of LTP. Science 265:1104-1107.

Nicoll RA, Malenka RC (1995) Contrasting properties of two forms of long-term potentiation in the hippocampus. Nature 377:115-118.

Nicoll RA, Kauer JA, Malenka RC (1988) The current excitement in long-term potentiation. Neuron 1:97-103.

Nielsen MD, Chan GCK, Poser SW, Storm DR (1996) Differential regulation of type I and type VIII Ca ${ }^{2+}$-stimulated adenylyl cyclases by $\mathrm{G}_{\mathrm{i}}$-coupled receptors in vivo. J Biol Chem 271:33308-33316.

Reddy R, Smith D, Wayman G, Wu Z, Villacres EC, Storm DR (1995) Voltage-sensitive adenylyl cyclase activity in cultured neurons. J Biol Chem 270:14340-14346.

Salin PA, Malenka RC, Nicoll RA (1996a) cAMP mediates a presynaptic form of LTP at cerebellar parallel fiber synapses. Neuron 16:797-803. 
Salin PA, Scanziani M, Malenka RC, Nicoll RA (1996b) Distinct shortterm plasticity at two excitatory synapses in the hippocampus. Proc Natl Acad Sci USA 93:13304-13309.

Salomon Y, Londos D, Rodbell M (1974) A highly sensitive adenylate cyclase assay. Anal Biochem 58:541-548.

Schwegler H, Crusio WE, Lipp HP, Heimrich B (1988) Water maze learning in the mouse correlates with variation in hippocampal morphology. Behav Genet 18:153-165.

Scoville WB, Milner B (1957) Loss of recent memory after bilateral hippocampal lesions. J Neurol Neurosurg Psychiatry 20:11-21.

Siegelbaum SA, Kandel ER (1991) Learning-related synaptic plasticity: LTP and LTD. Curr Opin Neurobiol 1:113-120.

Silva AJ, Simpson EM, Takahashi JS, Lipp HP, Shigetacla N, Wehner JA, Giese KP, Tully T, Abel T, Chapman PF, Fox K, Grant S, Itohara S, Lathe R, Mayford M, McNamara JO, Morris RJ, Picciotto M, Roder J, Shin HS, Slesinger PA, Storm DR, Stryker MP, Wolfer DP (1997) Mutant mice and neuroscience: recommendations concerning genetic background. Neuron 19:755-759.

Stanton PK, Sarvey JM (1985a) Blockade of norepinephrine-induced long-lasting potentiation in the hippocampal dentate gyrus by an inhibitor of protein synthesis. Brain Res 361:276-283.

Stanton PK, Sarvey JM (1985b) The effect of high-frequency electrical stimulation and norepinephrine on cyclic AMP levels in normal versus norepinephrine-depleted rat hippocampal slices. Brain Res 358: 343-348.

Sutherland RJ, Whishaw IQ, Kolb B (1983) A behavioral analysis of spatial localization following electrolytic, kainate- or colchicineinduced damage to the hippocampal formation in the rat. Behav Brain Res 7:133-153.

Suzuki T (1994) Protein kinases involved in the expression of long-term potentiation. Int J Biochem 26:735-744.

Thomas MJ, Moody TD, Makhinson M, O’Dell TJ (1996) Activitydependent $\beta$-adrenergic modulation of low frequency stimulation induced LTP in the hippocampal CA1 region. Neuron 17:475-482.

Thompson RF (1992) Memory. Curr Opin Neurobiol 2:203-208.

Treves A, Rolls ET (1992) Computational constraints suggest the need for two distinct input systems to the hippocampal CA3 network. Hippocampus 2:189-199.

Trudeau LE, Emery DG, Haydon PG (1996) Direct modulation of the secretory machinery underlies PKA-dependent synaptic facilitation in hippocampal neurons. Neuron 17:789-797.

Urban NN, Barrionuevo G (1996) Induction of Hebbian and nonHebbian mossy fiber long-term potentiation by distinct patterns of high-frequency stimulation. J Neurosci 16:4293-4299.

Villacres EC, Wu Z, Hua W, Nielsen MD, Watters JJ, Yan C, Beavo J, Storm DR (1995) Developmentally expressed $\mathrm{Ca}^{2+}$-sensitive adenylyl cyclase activity is disrupted in the brains of type I adenylyl cyclase mutant mice. J Biol Chem 270:14352-14357.

Wayman GA, Impey S, Wu Z, Kindsvogel W, Prichard L, Storm DR (1994) Synergistic activation of the type I adenylyl cyclase by $\mathrm{Ca}^{2+}$ and $\mathrm{G}_{\mathrm{s}}$-coupled receptors in vivo. J Biol Chem 269:25400-25405.

Weisskopf MG, Castillo PE, Zalutsky RA, Nicoll RA (1994) Mediation of hippocampal mossy fiber long-term potentiation by cyclic AMP. Science 23:1878-1882.

Wu Z, Wong ST, Storm DR (1993) Modification of the calcium and calmodulin sensitivity of the type I adenylyl cyclase by mutagenesis of its calmodulin binding domain. J Biol Chem 268:23766-23768.

Wu Z, Thomas SA, Villacres EC, Xia Z, Simmons ML, Chavkin C, Palmiter RD, Storm DR (1995) Altered behavior and long-term potentiation in type I adenylyl cyclase mutant mice. Proc Natl Acad Sci USA 92:220-224.

Xia Z, Storm DR (1997) Calmodulin regulated adenylyl cyclases and neuromodulation. Curr Opin Neurobiol 7:391-396.

Xia Z, Refsdal CD, Merchant KM, Dorsa DM, Storm DR (1991) Distribution of mRNA for the calmodulin-sensitive adenylate cyclase in rat brain: expression in areas associated with learning and memory. Neuron $6: 431-443$.

Xia Z, Choi EJ, Wang F, Blazynski C, Storm DR (1993) Type I calmodulin-sensitive adenylyl cyclase is neural specific. J Neurochem 60:305-311.

Xia Z, Choi EJ, Blazynski C, Storm DR (1995) Do the calmodulinstimulated adenylyl cyclases play a role in neuroplasticity? Behav Brain Sci 18:429-440.

Zalutsky RA, Nicoll RA (1990) Comparison of two forms of long-term potentiation in single hippocampal neurons. Science 248:1619-1624.

Zucker RS (1989) Short-term synaptic plasticity. Annu Rev Neurosci 12:13-31. 